\title{
INTERNAL FRICTION OF $\mathrm{Li}_{7} \mathrm{La}_{3} \mathrm{Zr}_{2} \mathrm{O}_{12}$ BASED LITHIUM IONIC CONDUCTORS
}

\begin{abstract}
The diffusion mechanisms of lithium ions in tetragonal phase as well as in $\mathrm{Al}$ and $\mathrm{Nb}$ stabilized cubic $\mathrm{Li}_{7} \mathrm{La}_{3} \mathrm{Zr}_{2} \mathrm{O}_{12}$ compounds were investigated by low-frequency internal friction technique. In the cubic $\mathrm{Li}_{7} \mathrm{La}_{3} \mathrm{Zr}_{2} \mathrm{O}_{12}$ phase, a remarkable relaxation-type internal friction peak $\mathrm{P}_{\mathrm{C}}$ with a peak height up to 0.12 was observed in the temperature range from $15^{\circ} \mathrm{C}$ to $60^{\circ} \mathrm{C}$. In the tetragonal phase however, the height of the $\mathrm{P}_{\mathrm{T}}$ peak dropped to 0.01 . The obvious difference of the relaxation strength between the cubic and tetragonal phases is due to the different distribution of lithium ions in lattice, ordered in the tetragonal phase and disordered in the cubic phase. Based on the crystalline structure of the cubic garnet-type $\mathrm{Li}_{7} \mathrm{La}_{3} \mathrm{Zr}_{2} \mathrm{O}_{12}$ compound, it is suggested that the high internal friction peak in the cubic phase may be attributed to two diffusion processes of lithium ions: $96 \mathrm{~h} \leftrightarrow 96 \mathrm{~h}$ and $96 \mathrm{~h} \leftrightarrow 24 \mathrm{~d}$.
\end{abstract}

Keywords: Lithium ionic conductor, $\mathrm{Li}_{7} \mathrm{La}_{3} \mathrm{Zr}_{2} \mathrm{O}_{12}$, internal friction

\section{Introduction}

Crystalline Li-rich oxides with a high ionic conductivity are of great importance because of their potential application in rechargeable batteries, powerful supercapacitors and electrochromic displays. Weppner et al. [1,2] initially reported a novel lithium ionic conductors with garnet-like structure, then much attention on the $\mathrm{Li}_{7} \mathrm{La}_{3} \mathrm{Zr}_{2} \mathrm{O}_{12}$ based compounds were attracted owing to its good ionic conductivity and high chemical stability, and thus it have been suggested as a promising solid electrolyte for all-solid-state rechargeable batteries.

Recently, the crystal structure, conduction property and lithium ion diffusion mechanism of $\mathrm{Li}_{7} \mathrm{La}_{3} \mathrm{Zr}_{2} \mathrm{O}_{12}$ oxide have been widely investigated by different experimental methods. Geiger [2] reviewed the crystal structure and lithium ion distribution of $\mathrm{Li}_{7} \mathrm{La}_{3} \mathrm{Zr}_{2} \mathrm{O}_{12}$ compound; two different phases occur: cubic at high temperature and tetragonal at low temperature. For the tetragonal phase with space group $I 4_{1} / \mathrm{acd}$, the low crystalline symmetry and ordered distribution of lithium ions exhibit a poor ionic conductivity $\left(\sim 10^{-6} \mathrm{~S} / \mathrm{cm}\right.$ at $300 \mathrm{~K}$ ). However, in the cubic structure with space group $I a-3 d$, the lithium ions partially occupy the sites of lattice and disorderly distribute in lattice. Such a structure results in a good conductivity up to $3.1 \times 10^{-4} \mathrm{~S} / \mathrm{cm}$ at room temperature. In order to stabilize the cubic phase in room temperature, partial cationic substitutions [3-8], such as Li by $\mathrm{Al}$ and $\mathrm{Zr}$ by Ta, $\mathrm{Nb}$, $\mathrm{Si}, \mathrm{Ga}$ or $\mathrm{Y}$, are suggested. It is known that the migration ability of lithium ions via vacancies plays a significant role in the solid lithium electrolytes. The present study is focused on the mechanism of lithium ionic diffusion in the tetragonal lattice as well as $\mathrm{Al}$ and $\mathrm{Nb}$ stabilized cubic $\mathrm{Li}_{7} \mathrm{La}_{3} \mathrm{Zr}_{2} \mathrm{O}_{12}$ compounds.

\section{Experimental}

Polycrystalline powders of pure $\mathrm{Li}_{7} \mathrm{La}_{3} \mathrm{Zr}_{2} \mathrm{O}_{12}$, partial $\mathrm{Al}$ substitution at $\mathrm{Li}$ site and $\mathrm{Nb}$ substitution at $\mathrm{Zr}$ site were prepared using solid state reaction method. The initial materials are high purity $\mathrm{La}(\mathrm{OH})_{3}(99.99 \%), \mathrm{Li}_{2} \mathrm{CO}_{3}(99.9 \%)$, $\mathrm{ZrO}_{2}(99.9 \%), \mathrm{Al}_{2} \mathrm{O}_{3}(99.9 \%)$, and $\mathrm{Nb}_{2} \mathrm{O}_{5}(99.9 \%)$. In order to compensate the evaporation loss of lithium at high temperature, an extra of $10 \mathrm{wt} . \%$ lithium was added into reaction mixtures, and the detailed synthesis processes had been reported in our previous work [9]. Powder X-ray diffraction (XRD) was used to identify the crystal phase of pure $\mathrm{Li}_{7} \mathrm{La}_{3} \mathrm{Zr}_{2} \mathrm{O}_{12}$ and cationic stabilized oxides with $\mathrm{Cu}-\mathrm{K} \alpha$ radiation (X'pert MPD PRO diffractometer) in the scanning range of $10^{\circ}$ to $70^{\circ}$ with a step of $0.033^{\circ}$. The low frequency internal friction (referred to as IF) measurements were carried out in a computercontrolled inverted torsion pendulum operating in the forced vibration mode [10]. The bar samples used in internal friction measurements with a dimension of about $50 \times 22 \times 1.2 \mathrm{~mm}^{3}$ were sawed from the sintered dense discs.

\section{Results and discussion}

Figure 1 presents the room temperature powder XRD patterns of pure $\mathrm{Li}_{7} \mathrm{La}_{3} \mathrm{Zr}_{2} \mathrm{O}_{12}, \quad \mathrm{Li}_{6.7} \mathrm{Al}_{0.1} \mathrm{La}_{3} \mathrm{Zr}_{2} \mathrm{O}_{12}$ and $\mathrm{Li}_{6.75} \mathrm{La}_{3} \mathrm{Zr}_{1.75} \mathrm{Nb}_{0.25} \mathrm{O}_{12}$, respectively. For the undoped $\mathrm{Li}_{7} \mathrm{La}_{3} \mathrm{Zr}_{2} \mathrm{O}_{12}$ sample, an obvious tetragonal splitting is observed, and the corresponding lattice constants were deduced as $a=13.126(2) \AA$ and $c=12.675(8) \AA$ with a cell ratio of $c / a=0.9657$ in terms of the Rietveld refinement of XRD data. For the $\mathrm{Al}$ and $\mathrm{Nb}$ stabilized $\mathrm{Li}_{7} \mathrm{La}_{3} \mathrm{Zr}_{2} \mathrm{O}_{12}$, the splitting lines

\footnotetext{
* KEY LABORATORY OF MATERIALS PHYSICS, INSTITUTE OF SOLID STATE PHYSICS, CHINESE ACADEMY OF SCIENCES, HEFEI 230031, CHINA

** AGH UNIVERSITY OF SCIENCE AND TECHNOLOGY, FACULTY OF METALS ENGINEERING AND INDUSTRIAL COMPUTER SCIENCE, AL. MICKIEWICZA 30, 30-059 KRAKÓW, POLAND

\# Corresponding author: xpwang@issp.ac.cn
} 
observed in the tetragonal phase disappear. The result exhibits a typical cubic garnet-type structure, and the lattice constant was determined as 12.964(9) $\AA$ for the cubic phase [11].

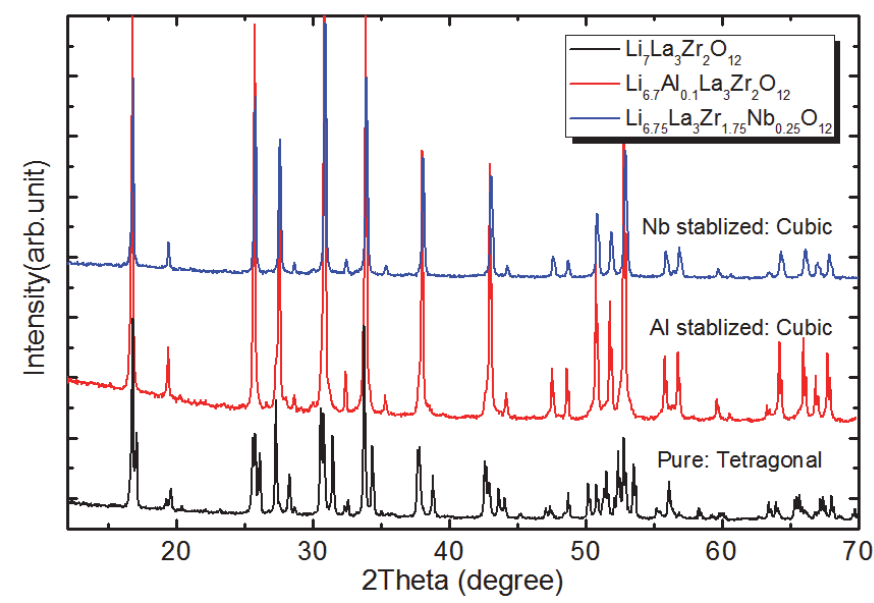

Fig. 1. XRD of the tetragonal, $\mathrm{Al}$ and $\mathrm{Nb}$ stabilized cubic $\mathrm{Li}_{7} \mathrm{La}_{3} \mathrm{Zr}_{2} \mathrm{O}_{12}$ compounds

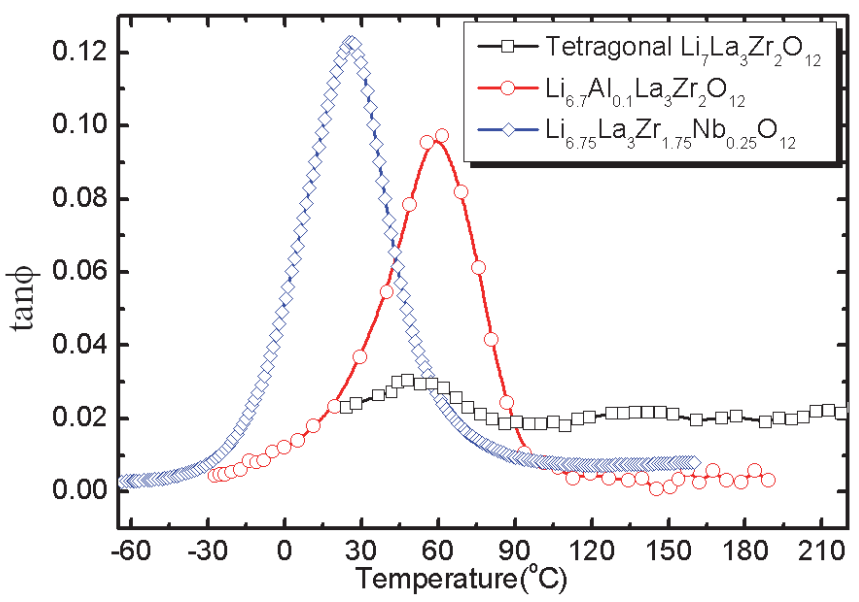

Fig. 2. The comparison of internal friction spectra in the tetragonal and $\mathrm{Al}, \mathrm{Nb}$ stabilized cubic $\mathrm{Li}_{7} \mathrm{La}_{3} \mathrm{Zr}_{2} \mathrm{O}_{12}$ compounds; the excitation frequency, $f=1 \mathrm{~Hz}$

Figure 2 shows the comparison of internal friction spectra observed in the tetragonal and $\mathrm{Al}, \mathrm{Nb}$ stabilized cubic $\mathrm{Li}_{7} \mathrm{La}_{3} \mathrm{Zr}_{2} \mathrm{O}_{12}$ compounds measured at $1 \mathrm{~Hz}$. A small internal friction peak (labeled as $\mathrm{P}_{\mathrm{T}}$ ) located at around $48^{\circ} \mathrm{C}$ is observed in the tetragonal phase. The peak height of the $\mathrm{P}_{\mathrm{T}}$ peak is only about 0.01 after background subtraction. On the contrary, the IF peak (labeled as $\mathrm{P}_{\mathrm{C}}$ ) in the cubic phase is very high. The relaxation strength of the $\mathrm{P}_{\mathrm{C}}$ peak reaches 0.1 and 0.12 for the $\mathrm{Al}$ and $\mathrm{Nb}$ stabilized $\mathrm{Li}_{7} \mathrm{La}_{3} \mathrm{Zr}_{2} \mathrm{O}_{12}$ samples, respectively. The peak temperature of the $\mathrm{P}_{\mathrm{C}}$ peak shifts towards a lower temperature of $25^{\circ} \mathrm{C}$ for the $\mathrm{Nb}$ stabilized cubic $\mathrm{Li}_{6.75} \mathrm{La}_{3} \mathrm{Zr}_{1.75} \mathrm{Nb}_{0.25} \mathrm{O}_{12}$ sample. In crystalline solids, the short-range diffusion of atoms or vacancies, can be described as the reorientation of elastic dipoles, which usually induces a relaxation type IF peak, as reported in oxygen ionic conductor $\mathrm{La}_{2} \mathrm{Mo}_{2} \mathrm{O}_{9}$ [12] and lithium ionic electrolyte $\mathrm{Li}_{5} \mathrm{La}_{3} \mathrm{Ta}_{2} \mathrm{O}_{12}$ [13]. In the $\mathrm{Li}_{7} \mathrm{La}_{3} \mathrm{Zr}_{2} \mathrm{O}_{12}$ based compounds, the mechanism for the two IF peaks is also ascribed to the short-range diffusion of lithium ions via vacancies. The point defects (e.g. lithium ions and vacancies) may be described as not only an electric dipole but also an elastic dipole. The difference in the peak height between $\mathrm{P}_{\mathrm{C}}$ peak and $\mathrm{P}_{\mathrm{T}}$ peak stems from the different distribution of lithium ions in the tetragonal and cubic phase.

In the tetragonal phase, the lithium ions distribute in an ordered state, and all Li sites with same symmetry are either fully occupied or completely empty, which leads to low diffusion mobility of lithium ions. An evidence is the poor conductivity in the tetragonal phase. In the high conductive cubic phase, lithium ions distribute in a disordered state, all $\mathrm{Li}$ sites with same symmetry are partially occupied. The partial accommodation and disordered distribution of lithium ions provide enough diffusion channels and thus greatly enhances diffusion mobility of lithium ions. According to the theory of point defect relaxation in crystalline solids, the relaxation strength shows a linear dependence on the defect concentration and the square of the dipole shape factor. It is suggested that the high IF peak observed in the $\mathrm{Al}$ and $\mathrm{Nb}$ stabilized cubic $\mathrm{Li}_{7} \mathrm{La}_{3} \mathrm{Zr}_{2} \mathrm{O}_{12}$ samples is associated with the high diffusion mobility of lithium ions, while the low IF peak in the tetragonal phase is ascribed to the lack of diffusion of lithium-vacancies because of the ordered accommodation of lithium ions in the lattice $[11,12]$.

Figure 3 presents the IF spectra of $\mathrm{Li}_{7-x} \mathrm{La}_{3} \mathrm{Zr}_{2-x} \mathrm{Nb}_{x} \mathrm{O}_{12}$ samples to investigate the effect of doping level on the diffusion of lithium ions. Moreover, for the $\mathrm{Li}_{7-x} \mathrm{La}_{3} \mathrm{Zr}_{2-x} \mathrm{Nb}_{\mathrm{x}} \mathrm{O}_{12}$ sample with $x=0.25$, the IF spectra measured at three different frequencies are also presented to further confirm the relaxation behavior of the IF peak in terms of the frequency dependence of the peak temperature. From the peak height of the $\mathrm{P}_{\mathrm{C}}$ peak, the relaxation strength linearly drops with increasing the $\mathrm{Nb}$ concentration in the range $x=0.25-1.5$, as shown in the inset of Fig. 3. It is suggested that the variation of IF peak height with the $\mathrm{Nb}$ content may be associated to the lattice contraction and the decrease of lithium ion concentration induced by the substitution of $\mathrm{Nb}$ at $\mathrm{Zr}$ sites. The effective radius of $\mathrm{Nb}^{5+}(0.78$ $\mathrm{nm})$ is smaller than that of $\mathrm{Zr}^{4+}(0.86 \mathrm{~nm})$ [13]. Increasing $\mathrm{Nb}$ content, the unit cell free volume of $\mathrm{Li}_{7-x} \mathrm{La}_{3} \mathrm{Zr}_{2-x} \mathrm{Nb}_{\mathrm{x}} \mathrm{O}_{12}$ samples will decrease and result in a decrease in diffusion mobility of lithium ions in lattice. On the other hand, the substitution of $\mathrm{Zr}^{4+}$ by $\mathrm{Nb}^{5+}$ also leads to decrease of lithium ion concentration due to the electrically neutral compensation, and thus lead to the decrease of the relaxation strength of the IF peak.

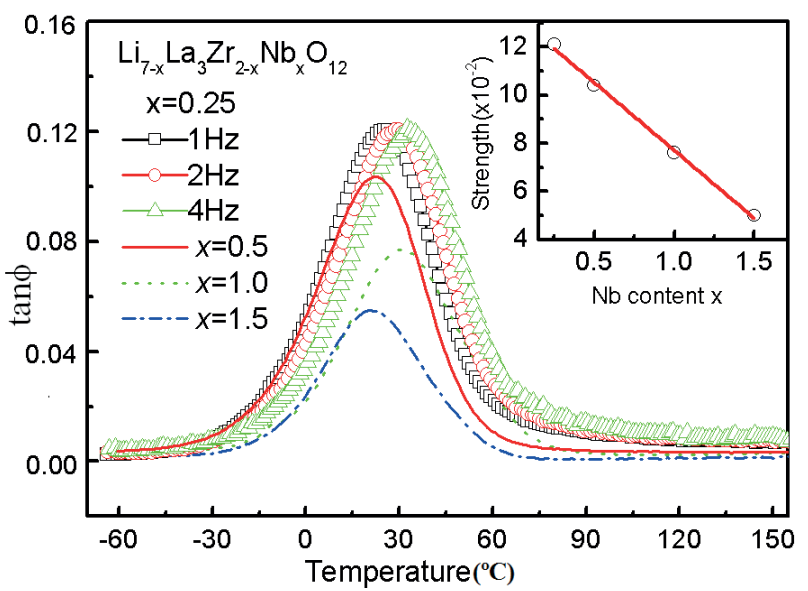

Fig. 3. Internal friction spectra of $\mathrm{Nb}$ doped $\mathrm{Li}_{7-x} \mathrm{La}_{3} \mathrm{Zr}_{2-x} \mathrm{Nb}_{x} \mathrm{O}_{12}$ samples. Inset: the peak height as a function of $\mathrm{Nb}$ content $x$ 
To elucidate the diffusion mechanism of lithium ions in $\mathrm{Li}_{7} \mathrm{La}_{3} \mathrm{Zr}_{2} \mathrm{O}_{12}$ based compounds, the broad $\mathrm{P}_{\mathrm{C}}$ peak in the cubic phase was fitted with two constituent peaks using a nonlinear fitting method, as shown in Fig. 4. The $\mathrm{P}_{\mathrm{C} 1}$ peak occurs on the lowtemperature side (peak height $=0.01$ ) and the $\mathrm{P}_{\mathrm{C} 2}$ peak is observed at higher temperature (peak height $=0.09$ ). The relaxation parameters are determined as $E_{1}=0.41 \sim 0.64 \mathrm{eV}$ for the $\mathrm{P}_{\mathrm{C} 1}$ peak and $E_{2}=0.35 \sim 0.56 \mathrm{eV}$ for the $\mathrm{P}_{\mathrm{C} 2}$ peak at different $\mathrm{Nb}$ content, and the corresponding pre-exponential factors are in the order of $10^{-}$ ${ }^{14} \sim 10^{-15} \mathrm{~s}$. The difference in the activation energies depends on the sites and concentration of doping elements. According to crystal symmetry and lithium ion distribution, the mechanisms of the two sub-peaks are suggested to originate from the two diffusion processes of lithium ions $[11,14]$ : $96 \mathrm{~h} \leftrightarrow 96 \mathrm{~h}$ for the $\mathrm{P}_{\mathrm{C1}}$ peak and $96 \mathrm{~h} \leftrightarrow 24 \mathrm{~d}$ for the $\mathrm{P}_{\mathrm{C} 2}$ peak, respectively. The schematic diffusion model is illustrated in Fig. 4.

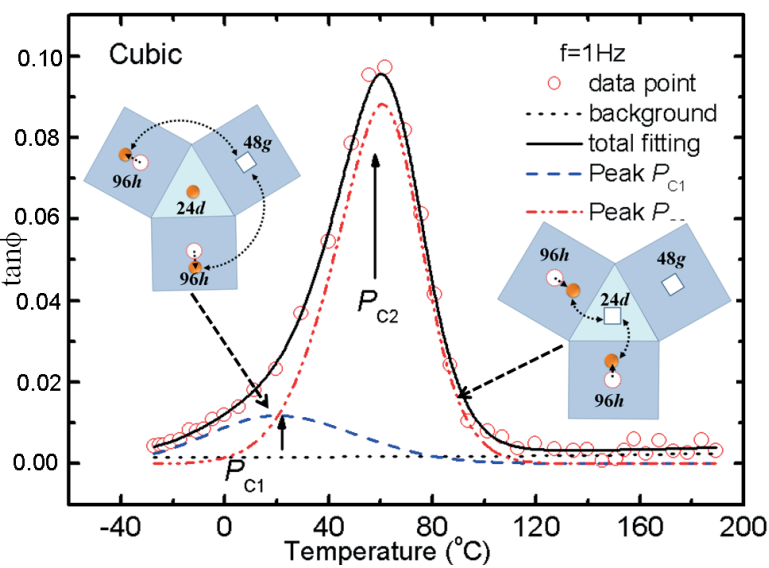

Fig. 4. Fitting results of the $\mathrm{P}_{\mathrm{C}}$ peak and diffusion model of lithium ions: $496 \mathrm{~h} \leftrightarrow 96 \mathrm{~h}$ for peak $\mathrm{P}_{\mathrm{C} 1}$ and $96 \mathrm{~h} \leftrightarrow 24 \mathrm{~d}$ for the $\mathrm{P}_{\mathrm{C} 2}$ peak

For the tetragonal phase, the relaxation mechanism of the $\mathrm{P}_{\mathrm{T}}$ peak is similarly ascribed to the diffusion process between neighboring octahedral and tetrahedral vacant sites. Thus, the stable and ordered distribution of lithium ions is responsible for the small relaxation strength.

\section{Conclusions}

The correlation between internal friction and crystal structure of the $\mathrm{Li}_{7} \mathrm{La}_{3} \mathrm{Zr}_{2} \mathrm{O}_{12}$ based electrolytes is reported. The $\mathrm{P}_{\mathrm{T}}$ peak observed in the tetragonal phase only exhibits a small relaxation strength, while for the $\mathrm{Al}$ and $\mathrm{Nb}$ stabilized cubic phase, the $\mathrm{P}_{\mathrm{C}}$ peak is much higher. Different internal friction spectra observed in the cubic and tetragonal phases are attributed to different distributions of lithium ions in the lattice, that is, order in tetragonal phase and disorder in cubic phase. The mechanisms of the $\mathrm{P}_{\mathrm{C}}$ peak are tentatively suggested to originate from the two diffusion processes of lithium ions: $96 \mathrm{~h} \leftrightarrow 96 \mathrm{~h}$ and $96 \mathrm{~h} \leftrightarrow 24 \mathrm{~d}$.

\section{Acknowledgments}

This work was financially supported by the National Natural Science Foundation of China, Grant Nos. 11374299,
51401203 and by the National Science Centre (NCN) in Poland under grant No. N N507 249040.

\section{REFERENCES}

[1] M. Ramaswamy, T. Venkataraman, W. Weppner, Fast lithium ion conduction in garnet-type $\mathrm{Li}_{7} \mathrm{La}_{3} \mathrm{Zr}_{2} \mathrm{O}_{12}$, Angew. Chem. International edition 46, 7778-7781 (2007).

[2] C.A. Geiger, E. Alekseev, B. Lazic, M. Fisch, T. Armbruster, R. Langner, M. Fechtelkord, N. Kim, T. Pettke, W. Weppner, Crystal chemistry and stability of " $\mathrm{Li}_{7} \mathrm{La}_{3} \mathrm{Zr}_{2} \mathrm{O}_{12}$ " garnet: A fast lithium-ion conductor, Inorg. Chem. 50, 1089-1097 (2011).

[3] J.L. Allen, J. Wolfenstine, E. Rangasamy J. Sakamoto, Effect of substitution ( $\mathrm{Ta}, \mathrm{Al}, \mathrm{Ga}$ ) on the conductivity of $\mathrm{Li}_{7} \mathrm{La}_{3} \mathrm{Zr}_{2} \mathrm{O}_{12}$, J. Power Sources 206, 315-319 (2012).

[4] S. Kumazaki, Y. Iriyama, K.H. Kim, R. Murugan, K. Tanabe, K. Yamamoto, T. Hiryama, Z. Ogumi, High lithium ion conductive $\mathrm{Li}_{7} \mathrm{La}_{3} \mathrm{Zr}_{2} \mathrm{O}_{12}$ by inclusion of both $\mathrm{Al}$ and $\mathrm{Si}$, Electrochem. Commun. 13, 509-512 (2011).

[5] E. Rangasamy, J. Wolfenstine, J. Sakamoto, The role of Al and Li concentration on the formation of cubic garnet solid electrolyte, Solid State Ionics 206, 28-32 (2012).

[6] M. Xu, M.S.Park, J.M. Lee, T.Y. Kim, Y.S. Park, E. Ma, Mechanisms of $\mathrm{Li}+$ transport in garnet-type cubic $\mathrm{Li}_{3+x} \mathrm{La}_{3} \mathrm{M}_{2} \mathrm{O}_{12}$ (M = Te, Nb, Zr), Phys. Rev. B 85, 052301 (2012).

[7] R. Murugan, S. Ramakumar, N. Janani, High conductive yttrium doped $\mathrm{Li}_{7} \mathrm{La}_{3} \mathrm{Zr}_{2} \mathrm{O}_{12}$ cubic lithium garnet, Electrochem. Commun. 13, 1373-1375 (2011).

[8] S. Ohta, T. Kobayashi, T. Asaoka, High lithium ionic conductivity in the garnet-type oxide $\mathrm{Li}_{7-x} \mathrm{La}_{3}\left(\mathrm{Zr}_{2-x} \mathrm{Nb}_{x}\right) \mathrm{O}_{12}$ ( $x=0 \sim 2)$, J. Power Sources, 196, 3342-3345 (2011).

[9] X.P. Wang, Y. Xia, J. Hu, Y.P. Xia, Z. Zhuang, L.J. Guo, H. Lu, T. Zhang, Q.F. Fang, Phase transition and conductivity improvement of tetragonal fast ionic electrolyte $\mathrm{Li}_{7} \mathrm{La}_{3} \mathrm{Zr}_{2} \mathrm{O}_{12}$, Solid State Ionics 253, 137-142 (2013).

[10] Y.T. Wen, Z.G. Zhu, F.K. Xie, X.Q. Yang, K.H. Liu, J.Y. Tan, C.Y. Xie, Multifunctional internal friction apparatus, Proceeding of the $2^{\text {nd }}$ National Conference on Internal Friction and Ultrasonic Attenuation in Solids, 133-134 (1988) (in Chinese).

[11] X.P. Wang, Y.X. Gao, Y.P. Xia, Z. Zhuang, T. Zhang, Q.F. Fang, Correlation and mechanism of lithium ion diffusion with crystal structure in $\mathrm{Li}_{7} \mathrm{La}_{3} \mathrm{Zr}_{2} \mathrm{O}_{12}$ revealed by internal friction technique, Phys. Chem. Chem. Phys. 16, 7006-7014 (2014).

[12] X.P. Wang, D. Li, Q.F. Fang, Z.J. Cheng, G. Corbel, P. Lacorre, Phase transition process in oxide-ion conductors $\beta-\mathrm{La}_{2} \mathrm{Mo}_{2} \mathrm{O}_{9}$ accessed by internal friction method, Appl. Phys. Lett. 89, 021904 (2006).

[13] X.P. Wang, W.G. Wang, Y.X. Gao, T. Zhang, Q.F. Fang, Low frequency internal friction study of lithium-ion conductor $\mathrm{Li}_{5} \mathrm{La}_{3} \mathrm{Ta}_{2} \mathrm{O}_{12}$, Mater. Sci. Eng. A 521-522, 87-89 (2009).

[14] Y. Xia, X.P. Wang, Y.X. Ga, J. Hu, Z. Zhuang, L.J. Guo, Q.F. Fang, C.S. Liu, Correlation of lithium ionic diffusion with $\mathrm{Nb}$ concentration in $\mathrm{Li}_{7-x} \mathrm{La}_{3} \mathrm{Zr}_{2-x} \mathrm{Nb}_{x} \mathrm{O}_{12}$ evaluated by internal friction method, Chin. Phys. Lett. 31, 016201 (2014). 
